\title{
Eesti keele viitevahendid kirjeldustes ja jutustustes
}

\author{
RENATE PAJUSALU, HELEN HINT, MARIA REILE, PIIA TAREMAA
}

Viitamine on suhtluslik tegu, millega viiakse vastavusse referent ja keeleline väljend. Referent võib olla reaalse maailma isik, ese, olukord või sündmus, aga see võib olla ka mõni mõte, tekst või hoopis kujuteldav nähtus. Referent võib seega olla ükskõik mis, mida inimene keelekasutuses suudab käsitleda terviklikuna. Keeleline väljend, millega referendile viidatakse, võib olla üksik nimisõna (poiss, puu, inflatsioon), pikem nimisõnafraas (ilus isamaa, see pikakarvaline kass; too etendus, mis toimus eelmisel laupäeval), asesõna (see, mina, tema) või muu väljend (adverb, verbivorm jm). (Ariel 1990; Gundel jt 1993; Diessel 1999; Givón 2005; Abbott 2010; Kibrik 2011)

Viitamisvahendi valikul on kõige olulisem arusaadavus. Referendi esmamainimisel peaks vestluspartner suutma luua uue referendi, igal järgmisel mainimisel on vaja mõista, kas jutt käib samast referendist. Kui ühest referendist räägitakse pikemalt, moodustub viiteahel, mis koosneb kõigist fraasidest, millega sellele referendile viidatud on. Kuid viitamisvahenditega saab ka näiteks kujundada sotsiaalset konteksti, anda hinnanguid ja iseloomustada referenti. Õieti polegi referendid alati konkreetsed esemed ja isikud, vaid pigem meie kujutlused (representatsioonid) nendest vestluse toimumise hetkel. Seega on referendid diskursuse elemendid, mis sünnivad ja muutuvad suhtluse käigus. (Hanks 1990; Cornish 1999; Etelämäki 2009; Kibrik 2011)

Viitamist jagatakse traditsiooniliselt ekso- ja endofoorseks (Halliday, Hasan 1976) ehk deiktiliseks ja anafooriliseks (nt Kibrik 2011:34-37). Eksofoorse ehk deiktilise viitamise puhul tuvastatakse referent vestlusolukorra kaudu, näiteks kui osutatakse nähtaval olevale esemele või kõneldakse kohal olevast inimesest. Endofoorse ehk anafoorse viitamise puhul tuvastatakse referent diskursuse põhjal, näiteks võib selleks olla jutustuses mainitud tegelane, ese või olukord. Nende kahe viitamistüübi vahel ei ole siiski alati võimalik vahet teha, pealegi on viitamise põhimehhanismid samad (Talmy 2017). Lähtume ka siinses uurimuses sellest, et kahe viitamistüübi vahel pole selget piiri.

Eesti keeles on uuritud mitmesuguseid viitevahendeid (vt kokkuvõtet Pajusalu 2017b). Enamasti on lähenemine olnud selline, et on valitud keeleline vahend (näiteks pronoomenid või märatlejaga noomenifraasid) ja vaadeldud nende kasutuse seaduspärasusi. Siinse uurimuse eesmärk on aga analüüsida seda, kuidas saab viidata eri tüüpi referentidele. Lähtepunktiks pole seega mitte keeleline vorm, vaid referent. Samas liigitame saadud materjali siiski nii, et esile tuleksid eraldi demonstratiiv- ja personaalpronoomenid ning määratlejaga fraasid.

Uurimismaterjaliks on kaks andmestikku: ühes kirjeldavad emakeelsed eesti keele kõnelejad kolme reaalselt nende ümbruses olevat maja, teises jutustavad kolm 
lugu piltide põhjal (vt Hint jt 2017; Reile jt 2019). Seega kuulub materjali hulka eksofoorselt ehk deiktiliselt suurtele objektidele (majadele) ruumis viitamisi ja endofoorselt ehk anafoorselt inimestele ja objektidele jutustuses viitamisi ning vahepealseid juhtumeid (nt narratiivide esmamainimised ja korduvviitamised majadele). Lisaks eri situatsioonidele on tegemist kahe erineva suhtlustegevusega: ${ }^{1}$ eksofoorse majadele viitamise puhul on tegu kirjeldamisega, millel ajaline mõõde puudub, ja endofoorse inimestele ja asjadele viitamise puhul jutustamisega, milles sündmusi esitatakse ajalises järjestuses. Mõlemas situatsioonis kogusime materjali nii eesti kui ka soome ja vene keeles, eesmärgiga võrrelda eesti keelt teiste keeltega. Siinses artiklis vaatleme ainult eesti keele viitevahendeid, võrreldes kahte andmestikku omavahel (eesti, soome ja vene keele võrdlusest vt Hint jt 2017; Pajusalu jt 2018; Reile jt 2019; Hint jt 2020). Keskendus on kvalitatiivsel analüüsil, arvandmeid on esitatud eelkõige taustaks.

Viitevahendite liigitamisel tehakse enamasti vahet pronoomenitel ja proadverbidel, definiitsena ja indefiniitsena markeeritud nimisõnafraasidel ja ilma definiitsusmarkerita nimisõnafraasidel (Gundel jt 1993; Laury 2005; Kibrik 2011). Siinses käsitluses on vaadeldud ainult 3 . pöördes viitamist ning viitevahendid oleme liigitanud järgmiselt:

1) määratlejata ${ }^{2}$ (leksikaalne) noomenifraas koosneb ainult nimisõnast või nimisõnast ja selle täienditest (va määratlejad), nt maja, noorem poiss, väga pikk tokk;

2) määratleja(te)ga (leksikaalset) noomenifraasi täiendavad eelkõige demonstratiivpronoomenid ja -adverbid (ehk demonstratiivid) ning indefiniitsed pronoomenid, nt see maja, seal majas, see esimene maja seal, üks poiss, mingi nokamütsiga poiss;

3) iseseisev demonstratiiv on üksikuna lauseliikme positsioonis olev demonstratiivpronoomen (see, too) või demonstratiivadverb (siin, sealt jm);

4) personaalpronoomen on tema või $t a$;

5) nullviitamine on elliptilise, st leksikaalselt väljendamata subjektiga pöördeline verbivorm (seisab, jookseb jms);

6) relatiivlausega laiendatud fraas on konstruktsioon, milles noomenifraasile või demonstratiivile järgneb restriktiivne või mitterestriktiivne relatiivlause (maja, kus me oleme).

Loomulikult ei saa kahest situatsioonist (suurte objektide kirjeldamine ja lugude jutustamine) kogutud andmete põhjal ammendavalt kirjeldada eesti keele viitevahendite terviksüsteemi. Siiski lubab siinses artiklis analüüsitav materjal ja võrdlev meetod teha üldistusi, mida siiani eesti keele kohta teha pole olnud võimalik. Lisaks siinsele analüüsile on varem eraldi uuritud nt viitamist väikestele (käes hoitavatele) objektidele (Reile 2015, 2016, 2019; Reile jt ilmumas). Samuti on lähemalt vaadeldud viitamist eelkooliealiste laste suulistes narratiivides (Kirsipuu jt 2012).

\footnotetext{
${ }^{1}$ Suhtlustegevuse all mõistame keelelist sotsiaalset tegevust, mis on kõnelejatele äratuntav. Termin on pärit suhtluslingvistikast (vt nt Schegloff 2007: 8).

${ }^{2}$ Määratleja (ingl determiner) on nimisõna(fraasi) ase- või arvsõnaline laiend, mis näitab viidatu informatsioonilist või referentsiaalset staatust (vt Pajusalu 2017a: 382 jj).
} 
Esitleme kõigepealt meetodit ja materjali, seejärel analüüsime materjalis leidunud viitevahendeid kummaski andmestikus eraldi ja situatsioone omavahel võrreldes. Seejärel teeme kokkuvõtte sellest, milliste eesti keele viitevahendite kategooriate kohta materjali analüüsi tulemusel on võimalik järeldusi teha.

\section{Materjal ja meetod}

Siinse uurimuse materjaliks on kaks katselisel teel kogutud andmestikku, nimetame neid majade katseks ja narratiivide katseks. Mõlemal juhul on tegu katselises olukorras kogutud eesti keelt emakeelena kõnelejate suulise kõne salvestustega. Kummaski katses osalesid erinevad kõnelejad, ükski katseisik ei osalenud mõlemas katses. Katsete eesmärk oli salvestada (pool)spontaanset suulist teksti, mis sisaldaks viitavaid fraase eri referentide kohta. Kõnelejad ei teadnud, et uurimus keskendub viitamisele. Nagu eespool öeldud, erinevad andmestikud nii situatsiooni kui ka käimas oleva suhtlustegevuse poolest.

Majade katses palusime katsealustel kirjeldada kõigepealt kahte aknast nähtavat maja ja neid omavahel võrrelda. Seejärel paluti neid kahte maja võrrelda selle majaga, mille neljandal korrusel nad ise kõnelemise ajal viibisid (vt katsealustele antud juhendit pildil 1). Eesmärk oli koguda kolmele majale viitavaid fraase kahes erinevas situatsioonis: siis, kui võrreldavaid maju oli ainult kaks (üks lähemal ja teine kaugemal), ja siis, kui kirjeldatavate hulka lisandus kolmas maja (milles kirjeldused salvestati). Käimas olevat suhtlustegevust nimetame kirjeldamiseks (info edastamine ilma ajalise dimensioonita). Maju kirjeldas samas kohas 33 eesti emakeelega kõnelejat (neist 27 naist). Kirjeldused salvestati videokaameraga ja litereeriti, seejärel kodeeriti kõik majadele viitavad keelelised üksused. Selliselt saime 1677 keelelist üksust, mis viitasid ühele või mitmele kolmest majast.

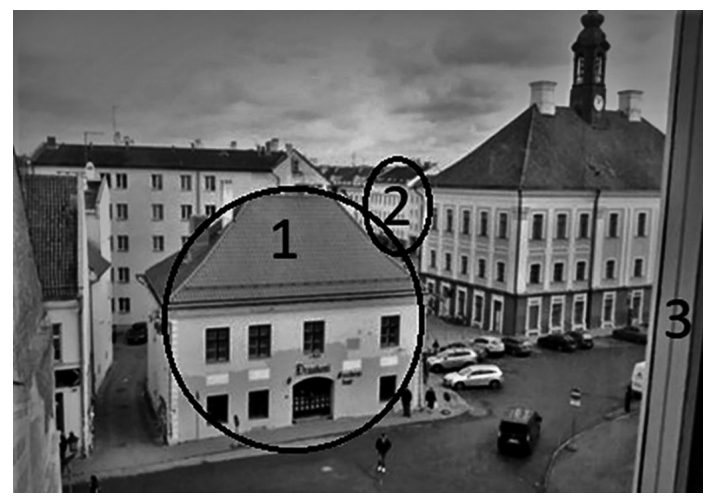

Pilt 1. Majade katse juhend osalejale (majade numbrid on lisatud artikli loetavuse huvides). 1. Pildil on märgitud kaks maja. Vaadake aknast välja ja kirjeldage ning võrrelge omavahel ringiga märgitud maju. 2. Palun kirjeldage nüüd maja, kus me sees oleme. Võrrelge seda maja ükshaaval ringiga märgitud majadega. 
Narratiivide katses jutustasid 20 emakeelset kõnelejat (neist 13 naist) kolm lugu pildiseeriate alusel. Jutustamisel paluti lähtuda sellest, et lugu peab olema arusaadav kellelegi, kes pilte ei näe. Lood olid ülesehituselt sarnased: algasid ühe poisi tegevusega, seejärel lisandus tegevusse teine poiss ja osales sündmustes. Lisaks kahele poisile oli igas loos kolm olulist füüsilist objekti: tuulelohe, pikk tokk, puu; õunapuu, kastekann ja õun; jalgratas, vana esiratas ja uus esiratas. Eesmärk oli salvestada (pool)spontaanset suulist kõnet, milles leiduks fraase, mis viitaks kahele poisile ja nendele objektidele. Käimasoleva suhtlustegevuse oleme nimetanud jutustamiseks (sündmuste edastamine ajalises dimensioonis). Materjal salvestati diktofoniga ja litereeriti, seejärel kodeeriti kõik eespool loetletud referentidele viitavad fraasid. Nõnda kogunes 1304 viiteüksust.
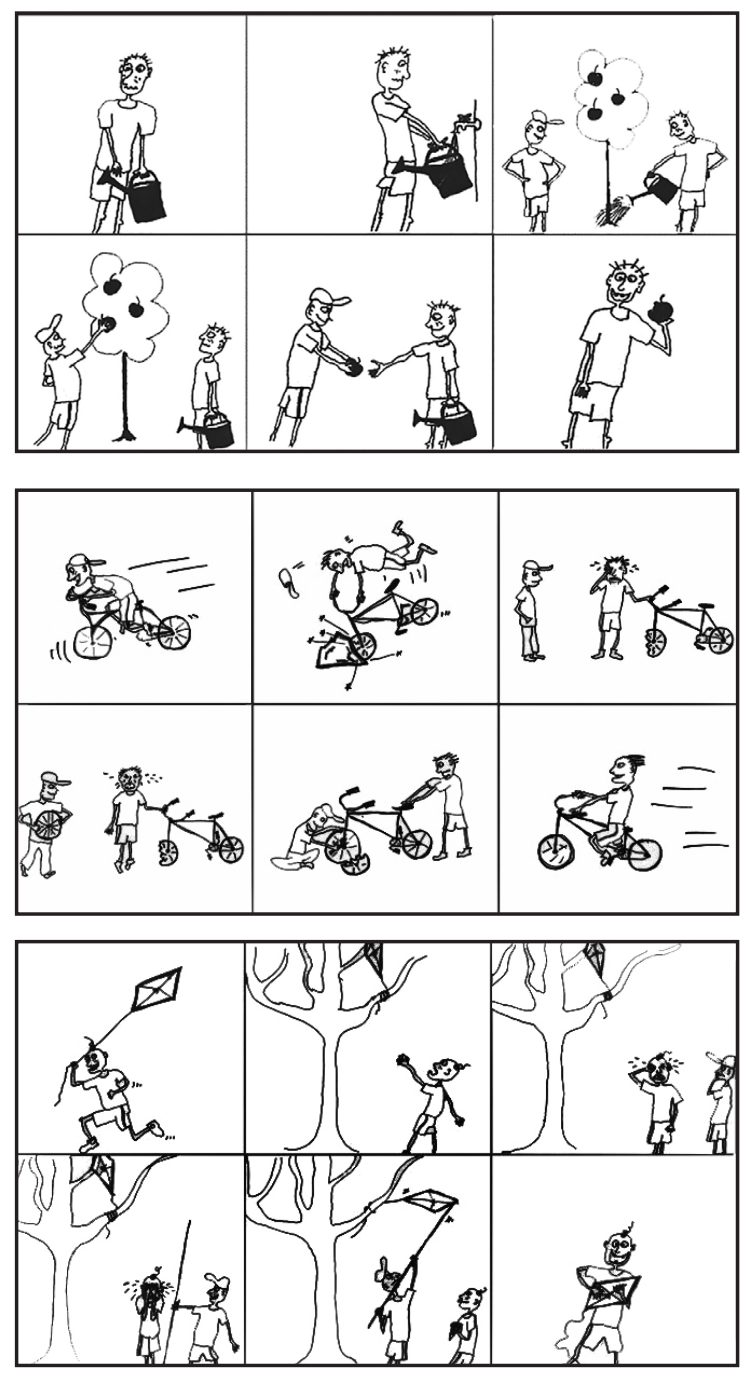

Pilt 2. Narratiivide katse pildiseeriad. 
Mõlemas andmestikus on tegemist monoloogidega. Majade katses kirjeldasid inimesed referente katse läbiviijale, kes andis minimaalse tagasiside abil mõista, et saab aru, millisest majast juttu on. Narratiivide katses juhiti jutustajate tähelepanu sellele, et lugudest peab aru saama ka pilte nägemata. Kõnelejad suutsid lahus hoida nn võistlevaid referente: esimeses katses maju ja teises poisse või objekte, millega poisid tegutsesid. Materjali analüüsides ei tekkinudki kordagi kahtlust, millisest referendist tegelikult räägitakse.

\section{Viitamine suurtele objektidele ruumis: majade katse}

Majade katses viidati kolmele majale ootuspäraselt palju nii määratlejaga kui ka määratlejata noomenifraaside $(62 \%$, lühend NP) ja iseseisvate demonstratiividega (23\%), personaalpronoomeneid oli oluliselt vähem (10\%) ning nullviitamisi (eksplitsiitse subjektita verbivorme) harva (3\%; tabel 1).

Tabel 1. Viitavate fraasitüüpide jagunemine majade kirjeldustes.

\begin{tabular}{|l|c|}
\hline Fraasitüüp & Sagedus \\
\hline Määratlejata noomenifraas (maja, tagumine maja) & $517(31 \%)$ \\
\hline Määratlejaga noomenifraas (see maja, too tagumine maja) & $515(31 \%)$ \\
\hline Iseseisev demonstratiiv (see, too, siin, seal) & $388(23 \%)$ \\
\hline Personaalpronoomen (ta, tema) & $175(10 \%)$ \\
\hline Nullviitamine (sarnaneb) & $45(3 \%)$ \\
\hline Personaalpronoomen/demonstratiiv mitmuses (nendel, neist) & $37(2 \%)$ \\
\hline Kokku & $1677(100 \%)$ \\
\hline
\end{tabular}

\subsection{Määratlejata leksikaalsed noomenifraasid}

31\% kõigist viiteüksustest oli noomenifraase, milles ei olnud ühtegi määratlejat. Enamasti oli tegemist leksikaalse noomenifraasiga, mille põhisõna on maja ja atribuudiks adjektiiv või $v$-kesksõna fraas, mis iseloomustab maja paiknemist, nt tagumine maja (näide 1), raekojaplatsi juures oleva tagumise majaga (näide 2), kaugemal asuv maja (näide 5). Majade võrdlemise käigus kasutati ka fraase, mille põhisõnaks oli maju omavahel võrdlev adjektiiv või järgarvsõna (tagumine, esimene, näited 1-3). Nimisõna laiendid olid selles olukorras seega sellised, et näitasid, mille alusel maju eristada. Enamasti moodustus kontrast distantsi alusel, kuid oli ka n-ö järjekorra alusel võrdlemist (esimene, teine).

Kuna soovisime eraldi vaadata just demonstratiiv- ja personaalpronoomenite esinemist, siis on tabelis 1 esitatud noomenifraaside rühmas ka mõni pronoomen (nt üks, teine, näide 4; mõlemad, näide 3), sh fraasid, kus pronoomenit laiendab elatiivne nimisõna (nt üks majadest). Mõni katseisik valis ka n-ö nimestrateegia, viidates lähedal olevale majale draakonimaja (näide 5) ja kaugemal olevale swedbanki maja, kolmandale majale lossi kolme maja (või nende nimede variantidega). 
(1) no vot esimene maja on kindlasti korruse võrra madalam kui on tagumine maja

(2) see maja kus me sees oleme see on (.) uuem maja? (.) eem võrreldes nii selle esimese majaga kui ka raekojaplatsi juures oleva tagumise majaga.

(3) ja kui nüüd nagu mõlemat võrrelda sis ongi see et ee (.) tagumisel mulle meeldib rohkem seina ja katuse tooni vahe.

(4) üks on siuke mõnus mada-masajas teine on siukene (.) sihvakama siluetiga

(5) ee (.) draakonimaja on kahekorruseline (.) ee kaugemal asev=asuv maja on (.) vähemalt kolmekorruseline (.) ja paistab et tal on katuseaknad

\subsection{Määratlejaga noomenifraasid}

Viitevahendite järgmise rühma (31\%) moodustasid määratlejaga noomenifraasid (näited 6-12). Kõige suurema rühma määratlejaid moodustasid majade katse andmestikus demonstratiivid (tabel 2). Nendest esinesid eelkõige demonstratiivpronoomenid see ja too ning demonstratiivadverbid siin ja seal enne noomenifraasi leksikaalset osa (näited 6 ja 7); demonstratiivadverbid esinesid ka pärast leksikaalset osa (näited 8-10).

Demonstratiivpronoomenit see kasutati nii esimesele, teisele kui ka kolmandale majale viitavana. Sellest võib järeldada, et see üksi distantsi ei erista. Ruumiline kontrast väljendus siis, kui kõneleja kasutas ka pronoomenit too. Selgemalt olid ruumiga seotud demonstratiivadverbid siin ja seal, sest kõige kaugemale majale ei viidatud kordagi fraasiga, mille määratleja positsioonis oleks olnud demonstratiivadverb siin, ja kõige lähemale majale (milles katsealused asusid) ei viidatud kordagi fraasiga, mille määratlejaks oleks olnud seal.

Tabel 2. Määratlejate jagunemine majade kirjeldustes.

\begin{tabular}{|l|r|}
\hline Määratleja & \multicolumn{2}{|l|}{ Sagedus } \\
\hline see & $371 \quad(66 \%)$ \\
\hline too & $19 \quad(3 \%)$ \\
\hline need & $55(10 \%)$ \\
\hline nood & $2 \quad(<1 \%)$ \\
\hline siin (siit, siia) & $48 \quad(9 \%)$ \\
\hline seal & $24 \quad(4 \%)$ \\
\hline Muud & $41 \quad(7 \%)$ \\
\hline Kokku & $573(100 \%)$ \\
\hline
\end{tabular}

Määratlejad on tabelis 2 esitatud algvormidena, hõlmates ka pronoomenite käändelisi vorme ja adverbide vorme siit ja siia (sealt ja sinna andmestikus määratlejatena ei esine). Ühes fraasis võis esineda ka mitu määratlejat (nt see maja seal), mistõttu on määratlejate arv tabelis 2 suurem määratlejaga fraaside arvust tabelis 1 . Kuna katseisikud kirjeldasid maju, ei läinud neil üldiselt vaja adverbide latiivseid ega separatiivseid vorme. Grammatiliselt lokatiivse määratlejana esinevad nii selles/tolles, sellel/ tollel kui ka siin/seal (näide 7). Tähenduse poolest on siin ja seal eelkõige ruumilised, demonstratiivpronoomenite inessiivi ja adessiivi vormide (selles, sellel, tolles, tollel) 
esinemine on aga tihedamini seotud omajatähendusega või rektsiooniga (sarnaselt tollele majale näites 6).

(6) et see (.) draakoni hotelli maja on alati see maja millest mina kui tartlane kui ma kui ma läbi linna jalutan siis mul kuidagi on see linnapildis olulisel kohal see maja sest ma pean alati tegema selle täisnurga ära ja jalutama ümber selle maja nurga ja siis ma alati näen selle maja fassaadi jaa...) ee (...) sarnaselt tollele majale ((osutab kapriisi majale)) on ka see maja ((osutab lossi majale)) minu arvates ühendatud (.) teiste majadega vist

(7) eem siis siin lähemal majal on ka üks silt mis ilmselt ütleb et see on arhitektuurimälestis ja või kes iganes siin majas on elanud, ilmselt vist arhitektuurimälestise silt, tollel tagumisel majal ei oska öelda kas on, ma arvan millegi pärast et ei ole

34 korral esines andmestikus aga samas noomenifraasis mitu demonstratiivi korraga, st nii pronoomen kui ka adverb. Põhiliselt esinesid kaks konstruktsiooni: demonstratiivpronoomen + noomenifraas + demonstratiivadverb (kokku 27 korda, nt sellel majal siin, näited 8 ja 9) ja demonstratiivadverb + demonstratiivpronoomen + noomenifraas (kokku 6 korda, nt siin selle hoone esimesel korrusel, näide 11). Mõnikord võis selline üksus sisaldada veel mõnda kohaadverbi, nt lähemal või taga(pool) (nt too hoone seal taga, näide 10). Ühel korral esines järjekord demonstratiivpronoomen + demonstratiivadverb + noomenifraas (see siin draakoni hotelli maja, näide 12). Sealjuures võis pronoomen see kombineeruda nii adverbiga siin kui ka seal (näited 8 ja 9), aga too (mis üldse oli harv) esines vaid adverbiga seal (näide 10).

Kahe demonstratiivi esinemist samas fraasis võiks näha kahe erineva tähenduse kombineerumisena. Näites 8 esitatud fraasis sellel majal siin kombineerus omajatähenduses sellel kohatähendust edastava adverbiga siin. Teiselt poolt võib tegemist olla ka n-ö kõneleja eneseparandusega: olles öelnud sellel majal, mõistab kõneleja, et see ei pruugi olla üheselt tõlgendatav, ja lisab siin, näites 9 aga seal.

(8) eem sellel majal siin on (.) ee selline uhke silmatorkav katus,

(9) see on (.) $\{-\}$ neljakorruseline maja vist (.) nagu ka see tagumine seal? (.)

(10) ehk siis kõigepealt eraldi võttes sis (.) too hoone seal taga (...) ee ma tean et on hästi vana hoone,

(11) ja aknad minu mäletamist mööda ei käi lahti siin selle hoone esimesel korrusel

(12) see (.) siin draakoni hotelli maja on hotell? (...)

Eelnevate näidete põhjal võib tekkida küsimus, kas mitme demonstratiiviga viiteüksused moodustavad ühe fraasi või on tegemist mitme fraasi kombinatsiooniga. Demonstratiivide kasutust koos nimisõnafraasiga on Heete Sahkai (2003) nimetanud topeldamiseks, mõeldes selle all seda, et samale referendile viidatakse kaks korda. Pausiga nimisõnast eraldatud demonstratiivi on Leelo Keevallik (2011) käsitlenud ka kohahoidjana. Meie materjalis leidus nii selliseid näiteid, kus fraasi terviklikkuses ei ole kahtlust, kui ka selliseid, mille tõlgendus võib olla erinev. Näidete 8 ja 9 fraasid on selged tervikud, näidete 11 ja 12 esimest demonstratiivi võib tõlgen- 
dada ka topelduse, kohahoidja või lisandina. Kuigi sellised mitme demonstratiiviga viiteüksused erinevad tüüpilisest noomenifraasist, on nad vähemalt siinse materjali järgi siiski enamasti viitesuhete vaatenurgast terviklikud ja võiksid olla käsitletud ühe fraasina.

\subsection{Iseseisvad demonstratiivid}

Sageduselt kolmas rühm (23\%) viiteüksusi oli majade katse materjalis iseseisvate demonstratiivide rühm. Üldise tendentsina võib öelda, et iseseisev demonstratiiv (siinses materjalis see, too, siin või seal) viitab majale teisel või järgneval mainimisel ega ole tüüpiliselt esmamainimise vahend (näited 13-17), v.a kui kõneleja alustab kirjeldamist lausekonstruktsiooniga see on... (näited 18 ja 19). Samasuguse iseseisva demonstratiiviga see viidati ka võrdluslausungites, kus mõlemast majast ühekaupa oli juba varem juttu olnud (näide 18). Too on siinses materjalis haruldane ja viitab peaaegu alati kaugemale majale. See võib viidata mis tahes majale, ka kaugemale. Kuigi just sellises võrdlevas ruumiliste objektide kirjelduses peaks olema ökonoomne kasutada ruumiliselt kontrastseid pronoomeneid see ja too, tuli selliseid juhtumeid üsna harva ette (vt siiski näidet 19).

Lisaks demonstratiivpronoomenitele kasutati ka demonstratiivadverbe siin (näide 16) ja seal (näited 15 ja 18). Kõige kaugemale majale viitamisel kasutati ainult adverbi seal, majale, milles katseisikud viibisid, viidati ainult adverbiga siin. Esimesele majale, mis asus kõnelejale suhteliselt lähedal (kuid siiski eemal), kasutati viitamisel mõlemaid demonstratiivadverbe, nii siin (näide 16) kui ka seal (näide 15).

Demonstratiivpronoomenite ja demonstratiivadverbide kasutust eristab kaks lausekonstruktsiooni: eksistentsiaallause seal on... (näited 15 ja 18) ja öeldistäitega esitluslause see on... (näited 17-19). Kui esitluslauset kasutati sagedamini esmamainimisel, siis adverbiga eksistentsiaallauset sagedamini siis, kui majast oli juba eelnevalt juttu olnud. Lausekonstruktsiooni süntaktiline erinevus kannab siin seega kahte eristust: lisaks referendi mõistestamise erinevusele (see/too füüsilise objektina ja siin/seal füüsilise ruumina) ka infostruktuurilist erinevust (esmamainimine see/ too puhul, järgnev mainimine siin/seal puhul).

(13) ei tea on mõeldud nagu (.) ee tuua vist mingisugust keskaegset imidžit sellele juurde

(14) aga taustal olev maja on (...) on sellises majade rivis. (...) selle poolest on on too nagu erinev.

(15) jaa mm (.) ja rohkem aknaid on, (.) päris palju aknaid on seal.

(16) ee esimene maja on väljast väga hästi valgustatud siin on lausa päris mitu valgustit ees aga \{seal\} tagumise maja puhul ma seda ei näe et oleks

(17) nii ongi see ((osutab draakoni maja poole)) on roosa maja (.) pigem roosakas,

(...) see on pigem hall, ((räägib lossi majast))

(18) see on draakoni baar (.) seal on svedbängi automaat

(19) et too ((räägib kõige kaugemast majast)) on ka suur hoone see ((räägib lähemast, draakonimajast)) on ka suur 


\subsection{Nullviitamised ja personaalpronoomenid}

Määratlejaga ja määratlejata noomenifraasid ja demonstratiivid moodustavad kokku $85 \%$ viiteüksustest. Lisaks viidati majadele 3\%-l juhtudest eksplitsiitse subjektita verbivormiga (näide 20) ja 10\%-l juhtudest personaalpronoomeniga (näide 21) ning 2\%-1 juhtudest mitmuslike vormidega, mida võib vormi järgi pidada nii demonstratiiv- kui ka personaalpronoomeniks (nt neist). Tema ja ta saavad elutule objektile viidata alles siis, kui see on referendina fookuses, see tähendab äsja viidatud (Pajusalu 2017b: 576-577). Majade katsele on aga iseloomulik, et majad kui referendid on kogu katse vältel nähtaval ning katseisiku jaoks infostaatuselt kõrgelt aktiveeritud. Päris esimene mainimine on toimunud juba katse juhendis, kus maju esitleti. Andmestikus ongi mainimiskord kodeeritud tinglikult, nii et esimeseks on loetud kõik sellised viitamised, millele on eelnenud viitamine mõnele teisele majale. Seetõttu esineb ka esimesel mainimiskorral sageli personaalpronoomeneid (tabel 3; vrd narratiivide katse tabeliga 6, kus esimesel mainimisel personaalpronoomeneid ei ole).

(20) siin on: äkki (.) ää neljandal oleme, (...) ma ei tea võibolla on sama kõrge kui see tagumine maja

(21) ee sellel majal on (.) vähem aknaid kui tollel tagumisel (.) ja (.) ja ta ei ole vist seotud mitte ühegi teise majaga

Materjalist nähtub, et iga järgneva mainimisega suureneb tõenäosus, et majale viidatakse pronoomenitega tema/ta, mitte see/too. Kui majast räägitakse pärast seda, kui vahepeal on räägitud mõnest teisest majast, on sagedam demonstratiiv, kui aga räägitakse pikemalt samast majast, osutatakse üha sagedamini sellele personaalproonomeniga (kuigi esineb ka demonstratiive).

Tabel 3. Iseseisvate demonstratiiv- ja personaalpronoomenite jagunemine majade katse andmestikus mainimiskordade lõikes.

\begin{tabular}{|l|c|c|}
\hline Mainimiskord & Demonstratiivpronoomen & Personaalpronoomen \\
\hline I & $81(42 \%)$ & $36(21 \%)$ \\
\hline II & $57(29 \%)$ & $51(29 \%)$ \\
\hline III & $23(12 \%)$ & $34(19 \%)$ \\
\hline Järgnev & $33(17 \%)$ & $54(31 \%)$ \\
\hline Kokku & $194(100 \%)$ & $175(100 \%)$ \\
\hline
\end{tabular}

Varasem uurimus (Pajusalu 2005) on näidanud, et eesti keele suulises kõnes esineb nominatiivis rohkem lühikest personaalpronoomenit $t a$ ja genitiivis pikka personaalpronoomenit tema. Ka majade katse materjalis esineb nominatiivis rohkem lühikesi vorme ta (105 nominatiivsest personaalpronoomenist 102 esines kujul ta, näide 21), kuid siiski ka pikki vorme tema. Genitiivis (kaassõnafraasis) eelistatakse pikka vormi tema (kõik kaheksa genitiivset vormi olid pikad, näide 22), adessiivis on valdavalt lühikesed vormid tal (kõik 26 adessiivset vormi olid kujul tal, näide 23). 
(22) ma ei oskagi nagu väga palju öelda tema kohta rohkem

(23) eem esimene maja asub- on eraldi, tal ta- tal ei ole ta ei külgne teiste majadega

\subsection{Relatiivlaused}

Noomenifraasid ja demonstratiivid võivad olla laiendatud ka relatiivlausega. Majade kirjeldustes oli relatiivlause lisatud 6\%-le võimalikest viiteüksustest. Relatiivlaused täpsustasid eelkõige referendi asukohta ja üldjuhul aitasid ka referenti tuvastada, olles seega restriktiivsed (näited 24 ja 25). Samas oli relatiivlause informatsioon mõnikord ka liiane, näites 26 on majad juba tuvastatud (katses on ainult üks kaugem maja ja ainult üks draakonimaja), kuid neile on siiski lisatud ka relatiivlause. Tuvastav (ehk identifitseeriv ehk restriktiivne) relatiivlause laiendas sageli eelteemat, kuuludes suulisele kõnele omase lahktarindi koosseisu (näide 25; vt Amon 2015; Hennoste 2017). Leidus ka mitteidentifitseerivaid relatiivlauseid, millega kõneleja lisas referendi kohta midagi olulist, nagu näites 27 , kus relatiivlause lisab juba identifitseeritud referendile oma omaduse - punase katuse. Majade katse materjalile oli siiski oluliselt omasem just identifitseerivate relatiivlausete kasutus.

(24) et raekoja platsi ääres (.) seisev maja on oluliselt suurem. kui see mis seisab siin meile lähemal.

(25) see maja kus me sees oleme see on (.) uuem maja?

(26) erinevus on veel see et ee (.) sellel kaugemal majal mis on raekojaplatsi ääres on ee (.) on katuseaknad katusel, selle draakonimajal mis lähemal on ei ole.

(27) see kahekorruseline maja milles siis on millel on punane katus, tundub olevat ka ahjuküte

\section{Viitamine tekstisisestele referentidele: narratiivide katse}

Narratiivide katse materjali viitevahendite jaotus on tabelis 4. Eesti keele suulistes narratiivides kasutati inimestele ja esemetele viitamisel kõige rohkem määratlejata noomenifraase (47\%; vrd 31\% majade katses) ning personaalpronoomeneid (20\%; vrd 10\% majade katses). Vähem esines määratlejaga laiendatud noomenifraase (14\%; vrd 31\% majade katses), nullviitamist (14\%; vrd 3\% majade katses) ning iseseisvaid demonstratiive (4\%; vrd 23\% majade katses).

Tabel 4. Viitavate fraasitüüpide jagunemine narratiivides.

\begin{tabular}{|l|r|}
\hline Fraasitüüp & Sagedus \\
\hline Määratlejata noomenifraas (mees, vana sõber) & $613(47 \%)$ \\
\hline Määratlejaga noomenifraas (üks poiss, see ratas) & $187(14 \%)$ \\
\hline Iseseisev demonstratiiv (see, too, siin, seal) & $51(4 \%)$ \\
\hline Personaalpronoomen (ta, nad) & $266(20 \%)$ \\
\hline Nullviitamine (vôttis) & $187(14 \%)$ \\
\hline Kokku & $1304(100 \%)$ \\
\hline
\end{tabular}




\subsection{Määratlejata leksikaalsed noomenifraasid}

Narratiivides kasutasid kõnelejad viitamiseks kõige rohkem (47\%) ilma määratlejata noomenifraase (näited 28-32). Nii elus kui ka elututele referentidele viitamisel esines nimisõna kas iseseisvalt (nt poiss, näide 28) või koos adjektiivatribuudiga, eelkõige adjektiiviga (nt katkise ratta, näide 29), aga ka verbi kesksõnaga (nt kukkunud härrasmehele, näide 30) või omadust väljendava nimisõnavormiga (nt nokatsiga sõber, näide 31). Elusatele referentidele (poistele) viitamiseks võeti narratiivides sageli kasutusele ka pärisnimi (nt Peeter, näide 32), kusjuures mõnel juhul kasutasid kõnelejad n-ö nimestrateegiat, st viitasid kogu diskursuses poistele vaid pärisnimega.

(28) siis poiss ei=saanud=seda tuulelohet=sealt enam kätte.

(29) ja=ta vahetab poisi (.) rattal (...) katkise ratta ära. (...)

(30) kes siis ää (...) tuli: kukkunud härrasmehele appi ratast parandama. (...)

(31) ja: nokatsiga sõber o- oskas ee ratast remontida? (.)

(32) Peeter kihutab jalgrattaga väga rõõmsa näoga.

\subsection{Mäcöratlejaga noomenifraasid}

Narratiivide andmestikus oli kokku 187 määratlejaga noomenifraasi, moodustades 14\% kõikidest viitevahenditest (tabel 5). Seega oli määratlejaid oluliselt vähem kui majade materjalis. Määratlejana esinesid erinevad pronoomenid ja demonstratiivadverbid, kuid kõige enam demonstratiivpronoomen see (50\%), indefiniitne pronoomen $\ddot{u} k s(23 \%)$ ning pronoomen oma (16\%). Indefiniitsete ja possessiivsete määratlejate suur sagedus oligi üks olulisemaid majade ja narratiivide andmestikku eristavaid omadusi, mis muidugi tuleneb kontekstide erinevusest.

Tabel 5. Määratlejate jagunemine narratiivides.

\begin{tabular}{|l|r|}
\hline Määratleja & \multicolumn{2}{|l|}{ Sagedus } \\
\hline see & $94 \quad(50 \%)$ \\
\hline$\ddot{u} k s$ & $43 \quad(23 \%)$ \\
\hline oma & $29 \quad(16 \%)$ \\
\hline mingi & $8 \quad(4 \%)$ \\
\hline seal (sinna, sealt) & $8 \quad(5 \%)$ \\
\hline too & $1 \quad(<1 \%)$ \\
\hline muud & $4 \quad(2 \%)$ \\
\hline Kokku & $187(100 \%)$ \\
\hline
\end{tabular}

Määratlejad on tabelis 5 esitatud algvormidena, hõlmates ka pronoomenite käändelisi vorme ja adverbide vorme seal, sinna ja sealt (siin, siia ja siit andmestikus ei esine). Määratlejat see sisaldav noomenifraas viitab diskursuses juba mainitud ja tuntud, st definiitsele referendile. Viidatud referent võib olla nii elus (näide 33) kui ka elutu (näide 34), tegu võib olla nii narratiivi keskse tegelase (näide 35) kui ka narratiivi tegevuse seisukohast vähem olulise referendiga (näide 36). 
(33) $\mathrm{a}=\mathrm{ja}=$ aga samal ajal on see: nokamütsiga poiss leidnud 'lahenduse=

(34) aa ja=selle ridva $=$ abil aitab selle tuulelohe $=$ sealt puu otsast alla. (...)

(35) se poiss läheb ee kraani juurde=

(36) ta võtab selle kaikaga tuulelohe: puu otsast alla?

Varem on näidatud, et indefiniitne artiklilaadne määratleja üks esineb referendi esmamainimisel, sellega viidatakse kuulaja jaoks veel tundmatule referendile ja sageli antakse ka märku narratiivi algusest (Pajusalu 2000: 104-105). Ka narratiivide materjalis viidati $\ddot{u} k s \mathrm{NP}$-ga nii elus (näide 37) kui ka elutule (näide 38) veel tundmatule referendile. Samuti toodi $\ddot{u} k s \mathrm{NP}$-ga sageli loo alguses diskursusesse nn peategelane (näide 39).

(37) seda kõike (.) nägi pealt=aga üks ää: (.) paljajalgne (.) külamees. (.)

(38) ja: (.) sõber tõi ühe pika toki, (.)

(39) ää (.) üks noormees (.) sõidab jalgrattaga.

Pronoomen oma erineb teistest määratlejatest selle poolest, et ei ole kindlalt seotud definiitsuse kategooria ega mainimiskorraga, vaid selle esmaseks funktsiooniks on referentidevahelise suhte väljendamine (Pajusalu 2017b). omaNP viitab ka narratiivide materjalis nii esmakordselt mainitud (näide 40) kui ka eelnevas diskursuses juba viidatud referendile (näide 41). Siiski, referentsiaalseid omaNP-sid võib viitesuhete aspektist vaadatuna pidada definiitseteks fraasideks, sest oma seob referendi diskursuses juba tuntud referendiga (vt täpsemalt Hint jt 2017).

(40) ilusal suvepäeval lennutas eää (.) e=üks poiss (.) oma: (.) ee tuulelohet.

(41) ta=nägi et se tuulelohe hakab oksa küljest lahti tulema=ja lõpuks=ta sai tänu sõbrale $=$ oma lohe $=$ ilusti kätte $=$

\subsection{Iseseisvad demonstratiivid}

Iseseisvaid demonstratiive kasutati narratiivides vaadeldud referentidele viitamisel 51 korral, st protsentuaalselt vähem kui majade katses (4\% narratiivides, 23\% majade katses). Neist 43 olid demonstratiivpronoomenid, iseseisvaid demonstratiivadverbe esines kaheksal korral, kusjuures adverbivormidest esinesid vaid sinna, seal ja sealt ning neid kasutati üksnes elututele referentidele (kastekann, õunapuu, puu) viitamisel. Iseseisvaid pronoomeneid ei kasutatud narratiivides kordagi referendi esmamainimisel (tabel 6), kuna tekstisiseses viitamises eeldab pronoomeni kasutus seda, et referenti on käimasolevas diskursuses varem mainitud.

Eelkõige on demonstratiivide vähesem kasutus tingitud sellest, et narratiivid keskendusid elusatele referentidele. Muidugi viidati ka narratiivides elututele referentidele ning nende teisel või järgmisel mainimisel vahetult esmamainimisele järgnevas lausungis on demonstratiivpronoomen tavaline (näide 42). Elutute referentide mainimisel jäi narratiivides sageli aga kahe mainimiskorra vahele lausungeid, kus seda referenti ei nimetatud. Sellisel juhul kasutati järgneval mainimisel pigem 
leksikaalset noomenifraasi (näide 43). Demonstratiivpronoomen võis aga teatud juhtudel viidata ka elusale referendile, nt eelnevas lauses muus kui subjekti positsioonis olnud referendile, juhul kui diskursuses oli parasjagu kaks (või enam) elusat referenti (näide 44). Seega võib demonstratiivpronoomen viidata inimreferendile (vähemalt) kontrasti olukorras.

Tabel 6. Iseseisvate demonstratiiv- ja personaalpronoomenite jagunemine narratiivides mainimiskordade lõikes.

\begin{tabular}{|l|l|l|}
\hline Mainimiskord & Demonstratiivpronoomen & Personaalpronoomen \\
\hline I & - & - \\
\hline II & $17(40 \%)$ & $31 \quad(12 \%)$ \\
\hline III & $7(16 \%)$ & $40(15 \%)$ \\
\hline Järgnev & $19(44 \%)$ & $192(73 \%)$ \\
\hline Kokku & $43(100 \%)$ & $263(100 \%)$ \\
\hline
\end{tabular}

(42) nii. see=on lugu ühest poisist kes lennutab tuulelohet? (.) kahjuks jääb see õ puu otsa kinni.

(43) 'pani uue esiratta (.) rattale. jaa: sis=oli poiss jälle rõõmus=ja sõitis rattaga edasi (44) siis see appit(h)ulnud poiss leiab puuoksa? mida=ta üritab pakkuda nutvale poisile. (.) ent=kuna too ei võta vedu

\subsection{Personaalpronoomenid}

Kolmanda isiku personaalpronoomen oli narratiivide materjalis väga sage (20\%). See esines üldjuhul lühikeses vormis $(t a, 84 \%)$, oluliselt vähem kasutati pikka vormi (tema, 16\%). Ootuspäraselt ei kasutatud kirjeldava sisu poolest vaest personaalpronoomenit narratiivides referendi esmamainimisel, vaid eelnevalt mainitud, seega tuntud referentide korduval mainimisel (tabel 6).

Narratiivide materjalis viitas personaalpronoomen üksnes elusatele referentidele, st ühele poistest või seitsmel korral ka kahele poisile korraga (nad). Nominatiivis tegevussubjekti puhul oli sagedam lühike vorm (näide 45). Samuti esines lühike vorm adessiivi käändes kogeja-omajalausetes (näide 46), või siis allatiivis (näide 47).

(45) aaga siis õnnetult=ta sõidab vastu kivi

(46) $\mathrm{ja}=$ tal lendab müts peast ära.

(47) sõber tuli talle appi.

Narratiivides, nagu ka majade katse materjalis, esines pikk personaalpronoomenivorm tema eelkõige genitiivatribuudina (näide 48), ühel korral ka koos relatiivlauselise lahktarindiga (näited 49 ja 50; lahktarindi kohta vt lähemalt Amon 2015). Näidetes 49 ja 50 on ka näha pika vormi tema kontrasti edastavat tähendust, kuna narratiivis on korraga kaks poissi.

(48) ja: sis=juhtub nimodi et tema: tuulelohe jääb puu otsa kinni

(49) aga aga see poiss kes haiget sai, (.) tema ainult nutab. (.) 
(50) ja siis nüüd see: poiss kes sin tuli, kes=ei kukkund rattaga, tema: toob ee sele nutvale katkise rattaga poisile uue ratta. (.)

\subsection{Nullviitamised}

(Suulises) keelekasutuses jäetakse juba tuntud referendile sageli eksplitsiitse fraasiga viitamata, seda eelkõige kontekstides, kus tegevussubjekt jääb mitme lausungi jooksul samaks ega esine konkureerivaid (elusaid) referente (vt ka Lindström 2005; Hint 2015). Sisuliselt on sel juhul tegu elliptiliste lausetega (vt Erelt 2017), ent kuna terminit verbieelse nominaalfraasi ellips kasutatakse struktuurilt ja tähenduselt väga erinevate kontekstide kohta, siis oleme siinse uurimuse jaoks mõistet kitsendanud ja peame eksplitsiitse subjektita verbivormi ehk nullviitamise all silmas konkreetset ellipsi alaliiki. Oluliselt sagedasem nullviitamise kasutus narratiivides võrreldes majade katse materjaliga ( $14 \%$ narratiivides, $3 \%$ majade katses) tuleneb osaliselt sellest, et sarnaselt personaalpronoomeniga on tegu eelkõige elusale referendile viitava vahendiga (näited 51 ja 52).

(51) no mingi tüüp kastekannuga (...) laseb kastekannu vett. (...) siis läheb mingi pu õuna puu juurde.

(52) mingi tüüp lennutab lohet. (...) lennutas lohe puu otsa. se=jäi sinna kinni. (.) hakkas nutma.

\subsection{Relatiivlaused}

Nagu ka majade katse materjalis, esines narratiivides relatiivlausega laiendatud noomenifraase ja demonstratiive (6\% kõigist viitefraasidest), kuid võrreldes majade katsega on relatiivlausetel narratiivides teistsugune roll. Eelkõige kasutati narratiivides mitterestriktiivseid relatiivlauseid, millega öeldi referendi kohta midagi uut (näide 53). Referenti identifitseerivate restriktiivsete relatiivlausete ja lahktarindit täiendavate relatiivlausete esinemine narratiivides on marginaalne (vt siiski näiteid 49 ja 50, kus need esinevad).

\section{(53) ilmub juurde (.) üks sõbralik noormees, (.) kes e vaatab huvitaval pilgul}

Narratiivide andmestiku põhjal saab laiemaid üldistusi teha vaid ainsuses olevate viitamisfraaside kohta. Materjalist kodeeritud 1304 viitavast fraasist olid vaid 14 (1\%) mitmuse vormis. Kuuel juhul viitas mitmuslik fraas kahele poisile ning kasutatud oli 3. isiku mitmuse lühikest pronoomenit nad või leksikaalset nimisõnafraasi poisid. Kaheksa mitmuses olevat fraasi viitas elututele referentidele, neis esinesid demonstratiivpronoomeni see mitmuslik vorm need, määratlejaga fraas need õunad ning laiendita mitmuslikud nimisõnafraasid (nt õunad). 


\section{Viitamisega seotud kategooriaid ja nähtusi}

Allpool analüüsime kategooriaid ja nähtusi, mis eespool käsitletud materjalis osutusid oluliseks viitevahendi valiku seisukohast: kontrast, distants ja tuntus ning sõltumine käimasoleva suhtlustegevuse ja süntaktilise konstruktsiooni omadustest. Püüame selle kaudu lisada uut infot nende kategooriate väljendumise kohta eesti keele viitevahendites.

\subsection{Kontrast}

Kontrasti on peetud oluliseks eesti keele pikkade ja lühikeste personaalpronoomenite kasutuse seletamisel - pika pronoomenivormiga viidatakse kontrastiolukorras, lühikesega aga mitte (Kaiser 2010; Pajusalu 2017b). Samuti on kontrasti nähtud demonstratiivpronoomenite kasutuse reguleerijana mitmes muude keelte demonstratiivide kasutuse uurimuses (Diessel 1999, 2012, 2013; Meira, Terrill 2005; Levinson 2018). Tegemist on üsna hägusa kategooriaga, sest kuigi kontrasti mõiste esineb viitamisvahendite uurimuses suhteliselt tihti, ei ole üheselt selge, mida selle all mõeldakse. Lihtne on näha kontrasti kahe või enama sama tüüpi referendi kooseksisteerimisel diskursuses, eriti kui neid referente võrreldakse omavahel. Selliseid sama tüüpi referente on nimetatud ka võistlevateks referentideks. Nii on kontrastis majade katse andmestiku esimeses katseolukorras esimene ja teine maja, teises olukorras esimene, teine ja kolmas maja. Narratiivides on kontrastis kaks poissi. Kas viitevahendeid mõjutavas kontrastis võiksid aga olla ka narratiivides esinevad üksteisest erinevad esemed? Objektide (meie materjalis tokk, lohe, ratas jms) identifitseerimisel on juba lauses esinev verb ära määranud, millise esemega tegemist on, ja jutustajal ega kuulajal ei teki just selle tõttu küsimustki, millisest esemest juttu on. Ei saa välistada, et kontrast võib narratiivis põhjustada ka erinevusi objektidele viitamisel, kuid selle tõestamiseks oleks vaja konteksti, kus nendega sooritatakse samu tegevusi. Teine probleem on see, kas kogu olukorras kontrastis olevad referendid võivad mikrotasandil ka mitte olla kontrastis. Ka majade katses, kus maju võrreldakse kogu aeg, võib kõneleja pikemalt keskenduda ühele majale ja nõnda võib laiema situatsiooni kontrast neutraliseeruda.

Siinkohal analüüsime olukorda, kus referentidele viidatakse mingi referentsiaalse vahendiga just seetõttu, et referendid on kontrastis (võrdluses) mingi teise, sama tüüpi referendiga. Seega ei püüa me kõikides viitamisjuhtudes leida, kas on tegemist kontrastiolukorraga või mitte (see oleks praktiliselt võimatu), vaid otsime viitevahendeid, mille kasutamise põhjuseks võiks olla kontrast. Kontrasti olukorras aitavad referenti identifitseerida ruumilise tähendusega sõnad ja väljendid (see - too, siin - seal, eesmine - tagumine jne), mitteruumilises kontekstis aga välimuse või tegevusega seotud väljendid (nt nokamütsiga poiss, nuttev poiss). Ruumilise kontrasti tingimustes võivad ka eesti keele see ja too eristada referente kauguse alusel. Muidu harva esinev too ongi kõige selgemalt kontrastiivse tähendusega, seda pronoomenit kasutatakse siis, kui referent on kõnelejast kaugel ja kontrastis teisega, mis on lähemal. Nii varasematest uurimustest (Pajusalu 2006) kui ka siinsest 
materjalist (näide 44) on teada, et ka endofoorselt viitab too just kontrastis olevale isikule, kes ei ole peategelane. Seega on kontrast oluline mõjutaja just pronoomeni too valikul.

Kontrast väljendub ka personaalpronoomenites. 3. isiku nominatiivne pikk vorm tema näitab enamasti, et kontekstis on ka teine, kontrastis olev referent, ja et kuulaja peab identifitseerimisel olema eriti tähelepanelik (näited 49 ja 50). Samas ei ole pronoomenitel tema ja ta referenti eristavat potentsiaali, st ka teisele, kontrastsele referendile, saab viidata pronoomeniga tema. Nii ta kui ka tema viitavad referendile, mis on kõige rohkem fookuses (enamasti on see ka viimati mainitud). Küll on aga kontrasti olukorras võimalik kaht võistlevat referenti eristada, kasutades personaalpronoomenit tema/ta ning vastandades seda demonstratiivpronoomeniga see/too. Siinses materjalis esines personaalpronoomeni vastandamist too-ga üsna harva (vt siiski näidet 44).

\subsection{Distants}

Distantsi ehk referendi kaugust kõnelejast on nii keelteüleselt (nt Diessel 1999, 2013; Dixon 2003) kui ka eesti keele demonstratiivide puhul (Larjavaara 1990; Reile 2015, 2016; Pajusalu 2017b; Reile jt 2019) peetud põhiliseks teguriks, mis mõjutab demonstratiivi valikut. Distantsi mõju viitevahendite valikul vaatlesime majade katses, kus referendid asusid katsealustega samas füüsilises ruumis. Referendi kaugust anti edasi nii nimisõna atribuutide kui ka demonstratiivide abil. Näiteks viidati lähemale majale, kasutades noomenifraasi eesmine maja, ja kaugemale majale, kasutades noomenifraasi tagumine maja. Demonstratiividest kasutati nii demonstratiivpronoomeneid see ja too kui ka demonstratiivadverbe siin ja seal ning nende kombinatsioone, nt see draakoni maja, too kaugem maja, see draakoni maja siin, too raekojaplatsi maja seal. Küll aga oli demonstratiivpronoomeni too kasutus harv (tabel 2), mistõttu on eesti keeles just demonstratiivadverbidel ning nende kombinatsioonidel demonstratiivpronoomeni(te)ga ruumilise eristuse juures suur tähtsus.

Oluline on, et majade katse olukorras toimis viitevahendi valikul mitu tegurit: ühelt poolt referendi ehk maja kaugus kõnelejast, teiselt poolt kontrastiivne olukord, ehk kirjeldada ja võrrelda tuli kaht (või kolme) maja. Kuigi on väidetud, et demonstratiivid ei kanna semantiliselt ruumilist tähendust, vaid omandavad selle pragmaatilises opositsioonis (nt Levinson 2004; Diessel 2012), võime eesti keele näitel väita, et päris nii see siiski ei ole. Kõige kaugemale majale ei viidatud kordagi demonstratiivadverbiga siin ja kõige lähemale majale (sellele majale, kus katsealused asusid), ei viidatud kordagi demonstratiivadverbiga seal. Samuti kasutati demonstratiivi too peaaegu ainult kõige kaugemale majale viitamiseks. Lisaks majade katse tulemustele on Reile jt (ilmumas) näidanud, et ka mittekontrastiivses olukorras, kui on vaid üks referent, millele tuleb viidata, võidakse kasutada demonstratiivpronoomenit see kõneleja lähedal olevale referendile ja demonstratiivpronoomenit too kõnelejast kaugel asuvale referendile osutamiseks. 
Seega võib järeldada, et eesti keele demonstratiivid kannavad endas suure tõenäosusega semantiliselt kauguse mõõdet, ${ }^{3}$ vähemalt suurte objektide ruumilisel viitamisel (nagu majade katses), kusjuures oluline on ka see, et demonstratiivadverbid on ruumiga tugevamalt seotud kui demonstratiivpronoomenid. Lisaks ilmneb kontrasti mõju eesti keele demonstratiivides eelkõige siis, kui referendid on nii üksteise kui ka kõneleja suhtes eri kaugusel.

\subsection{Tuntus}

Viitevahendi valik sõltub väga palju sellest, kas referent on varasemast tuttav või mitte. Tuntus ja referendi mainimiskord seostuvad tugevalt definiitsuse kategooriaga, mida eesti keeles küll grammatiliste vahenditega ei väljendata, kuid mis on pragmaatilisel tasandil ometi oluline (Lyons 1999). Nii on esimest korda mainitud referendid üldjuhul indefiniitsed, järgnevatel mainimiskordadel on tegu juba definiitsete referentidega. Kuna võimalike viitevahendite valik on aga oluliselt mitmekesisem kui binaarne definiitne-indefiniitne eristus seletada võimaldab, siis keeltevahelises võrdluses kasutatakse nn antuse hierarhiat (Gundel jt 1993). Antuse hierarhia sätestab kuus erinevat tuntuse (antuse) taset, neist kõrgeim on fookuses ja madalaim tüübina identifitseeritav. Nii paljude eristuste tegemine tegelikus materjalis on siiski üsna keerukas ning selle otstarbekus sõltub tugevalt ka keele üldisest viitevahendite süsteemist. Lisaks on uurijate seas järjest levinum seisukoht, et tuntus üksi ei määra kunagi viitevahendi valikut ning suurema seletusjõuga on vormispetsiifiline ja paljusid faktoreid arvestav lähenemine (nt Kaiser, Trueswell 2008; Kibrik jt 2016).

Oleme siinse materjali analüüsil lähtunud ainult mainimiskorrast, pidades sealjuures silmas, et majade katse materjalis toimub esmamainimine juba katse juhendis, mistõttu kodeeritud esimene, teine ja kolmas mainimine kajastavad mainimiskorda mikrokontekstis, mitte kogu situatsiooni tasandil. Siinne materjal kinnitab juba varem tehtud järeldusi eesti keele demonstratiivpronoomenite see ja too ning personaalpronoomenite tema ja ta omavahelise suhte kohta (vt nt Pajusalu 2005). Personaalpronoomen viitab eelkõige elusatele referentidele, nagu on näha narratiivide katse materjalis. Kui aga võistlevat elusat referenti ei ole (nagu majade katse materjalis), siis võib eelkõige $t a$, aga mõnes käändevormis (genitiiv) ka tema viidata elutule referendile, kusjuures iga järgmise mainimiskorraga ta esinemise sagedus suureneb. Vastavalt väheneb mainimiskordade arvu kasvades aga demonstratiivpronoomeni kasutussagedus. Võime siis öelda, et see viitab äsja mainitud, kuid veel suhteliselt uuele referendile, $t a$ aga väga tuntud, üksi fookuses olevale referendile. Seega on pronoomenivalikul tuntus väga oluline kategooria, mis toimib koos elususe kategooriaga. Tuntus võib osutuda olulisemaks referentsiaalse vahendi määrajaks kui elusus (kui kasutatakse ta elutu ja see elusa referendi kohta).

\footnotetext{
${ }^{3}$ Demonstratiivpronoomenit see on võimalik ruumis viitamisel kasutada ka ükskõik kui kaugel asuva referendi kohta, kuid vaid siis, kui demonstratiivpronoomen too kasutust ei leia. Selline olukord on võimalik juhul, kui too ei kuulu kõneleja aktiivsesse sõnavarasse (näiteks on kõneleja pärit põhjaeesti murdealalt), kuid ka siis, kui too-d viitamissituatsioonis mingil põhjusel parasjagu ei kasutata. Loe see distantsneutraalsuse kohta täpsemalt Reile 2019.
} 


\subsection{Suhtlustegevused ja viitevahendid: kirjeldamine ja jutustamine}

Analüüsisime viitevahendeid kahes suhtlustegevuses: kirjeldamises ja jutustamises. Kui narratiiv ehk jutustamine on saanud keeleteaduslikus kirjanduses palju tähelepanu (Labov, Waletzky 1967; Labov 1972: 354-396; Stein, Glenn 1979; Chafe 1980) ja selle määratluses - vähemalt kahe ajalises järgnevuses oleva lause esitamine ollakse enam-vähem ühel meelel, siis kirjeldus on saanud oluliselt vähem tähelepanu. Mõtleme kirjeldamise all referendi selliste omaduste esitamist, millel ei ole ajalist mõõdet.

Eri suhtlustegevused kasutavad keelelisi ressursse, sh viitamisvahendeid, erinevalt. Näiteks kasutati majade kirjeldustes palju lahktarindeid, mis koosnesid demonstratiivist, relatiivlausest ja demonstratiivi kordusest süntaktilise terviku osana (see, kus me sees oleme, see on..., näide 25). Narratiivides selliseid konstruktsioone peaaegu ei olnud, mis osalt oli ilmselt tingitud sellest, et narratiivid olid lähedasemad normeeritud kirjakeelele, teiselt poolt aga polnud neid ilmselt ka kõnelejatel vaja. See-eest oli narratiivides palju indefiniitse määratlejaga fraase (nt üks noormees, näited 37-39) ja omaNP-sid (nt oma lohe), mida ei esinenud majade kirjeldustes. Spetsiifilised viitevahendid tulenevad suhtlejate vajadustest, kordudes muutuvad aga suhtlustegevuste indeksiteks: kui kõneleja kasutab väljendit üks noormees, oskab kuulaja juba narratiivi oodata; kui aga kasutatakse lahktarindit see, kus me sees oleme, see on..., osatakse oodata midagi, mille puhul just referendi kindlaksmääramine on väga oluline.

Ka kasutatud viitevahendite üldpilt oli kirjeldamise ja jutustamise suhtlustegevuses erinev. Majade kirjelduses oli palju rohkem erinevaid viiteüksusi, mis näitab, et see suhtlustegevus oli kõnelejatele raskem ja neil oli vähem „valmis lahendusi”. Seda oletust tuleks siiski veel teistsugustes olukordades kontrollida.

\subsection{Viitevahendite süntaktilisi eripärasid}

Kahes vaadeldud kontekstis paistsid silma mõned süntaktilised eripärad, mida seni on eesti keele puhul vähe kirjeldatud. Kõigepealt tekitab siinse uurimuse vaatenurgast küsimusi nimisõnafraasi struktuur siis, kui talle järgneb demonstratiivadverb, nt see maja seal (vt ka Taremaa 2017). Viiteüksusena on kindlasti tegemist tervikuga, kuid kas seda peaks analüüsima ka süntaktiliselt ühe nimisõnafraasina? Saame seda teha, kui oletame, et selles fraasis on kaks määratlejat, üks (see) eelneb ja teine (seal) järgneb põhisõnale. Mitme määratleja kombinatsioone on eesti keeles varemgi kirjeldatud (see üks poiss, üks mingi tüdruk, vt nt Pajusalu 2017b), kuid need on paiknenud mõlemad enne põhisõna. Just ruumilise viitamise põhjalik uurimine on välja toonud järelpositsioonis määratleja tavapärasuse.

Ruumilise viitamise materjal majade katses näitas ka selliste lahktarindite sagedust, mis algavad määratlejaga noomenifraasiga või demonstratiivpronoomeniga, seejärel järgneb tuvastav (restriktiivne) relatiivlause ja siis demonstratiivpronoomen lauseliikmena (enamasti subjektina), nt see maja, mis siin eespool on, see on kollane. Marri Amon (2015), kes on siiani lahktarindeid eesti keeles kõige põhjalikumalt uurinud, kirjeldab lahktarindi olemust kui info andmist jaokaupa. See on kindlasti 
oluline ka majade katse materjalis. Kuna kõneleja peab samaaegselt kirjeldama maju ja hoolitsema selle eest, et kuulaja suudaks mõista, millisest parasjagu on jutt, on lahktarind mugav: kõigepealt tuvastatakse maja ja siis öeldakse selle kohta midagi.

\section{Kokkuvõte}

Artiklis vaadeldi eesti keele viitevahendeid kahes katselises olukorras, millest üks keskendus ruumilisele viitamisele (majade katse materjal), teine tekstisisesele viitamisele (narratiivide katse materjal). Kuigi mõlemad kontekstid olid loodud eelkõige eesti, soome ja vene keele võrdlemiseks, on siinses ülevaates esitatud ainult eesti keelt puudutavaid tendentse eri viitevahendite kasutamisel.

Materjalist selgus, et eesti keeles kasutatakse suhteliselt palju definiitseid ja indefiniitseid määratlejaid, kuid muidugi on ka palju määratlejata fraase. Definiitsed määratlejad (eriti see) on sagedased mõlemas andmestikus, narratiivides on aga palju ka indefiniitse määratleja $\ddot{u} k s$ ja pronoomeni oma kasutamist.

Demonstratiivpronoomenitest kasutatakse eelkõige pronoomenit see. Pronoomen too on harv ja osutab eelkõige kontrastile ja kaugusele. Ruumilise viitamise kõige tugevamad vahendid on adverbid siin ja seal. Ruumilise viitamise omapäraks on mitme määratlejaga fraasid, nt siin see maja, see maja seal. Kõnelejad kasutavad selliseid fraase enamasti ühe tervikliku viiteüksusena.

3. isiku personaalpronoomenid on eelkõige narratiivis sagedased tuntud referendile viitamise vahendid, kuigi korduval viitamisel tuleb neid ette ka ruumilises kontekstis. Pikk vorm tema esineb kontrasti olukorras, osutades sellele, et kontekstis on veel teine sarnaste omadustega referent.

Relatiivlaused on kontrastis olevate ruumiliste objektide kirjeldamises eelkõige identifitseerivas funktsioonis ja esinevad lahktarindi koosseisus, narratiivides aga eelkõige info lisamise funktsioonis ega esine üldjuhul lahktarindis.

Keelekasutajal on valida väga paljude viitevahendite hulgast, et ennast mõistetavalt väljendada. Viitevahendi valikut mõjutavaid faktoreid on maailma keeleteaduses palju uuritud. Siinse materjali põhjal võib väita, et eesti keeles on viitevahendi valiku peamisteks mõjutajateks referentide kontrast, kaugus, tuntus ning samuti mõned süntaktilised ja suhtlustegevuse laadiga seotud asjaolud. Siinsest materjalist ei selgu aga näiteks see, kas ja kuidas mõjutavad referentsiaalse vahendi valikut näiteks suhtumine referenti või selle kuulumine kõneleja või kuulaja sfärii, sest nende kategooriate uurimiseks on vaja teistsuguseid olukordi ja suhtlustegevusi.

Artikkel põhineb Eesti Teadusagentuuri uurimistoetuse PUT701 "Referentsiaalsed vahendid eesti ja naaberkeeltes: eksperimentaalne lähenemine" vältel tehtud uurimustel. Toetanud on ka Euroopa Regionaalarengu Fond Eesti-uuringute Tippkeskuse kaudu. 


\section{KIRJANDUS}

Abbott, Barbara 2010. Reference. (Oxford Surveys in Semantics and Pragmatics.) OxfordNew York: Oxford University Press.

Amon, Marri 2015. Initial and Final Detachments in Spoken Estonian: A Study in the Framework of Information Structuring. (Dissertationes linguisticae Universitatis Tartuensis 24.) Tartu: University of Tartu Press.

Ariel, Mira 1990. Accessing Noun-Phrase Antecedents. London: Routledge.

Chafe, Wallace L. 1980. The Pear Stories: Cognitive, Cultural, and Linguistic Aspects of Narrative Production. Norwood, N.J.: Ablex.

Cornish, Francis 1999. Anaphora, Discourse, and Understanding: Evidence from English and French. Oxford: Clarendon Press.

Diessel, Holger 1999. Demonstratives: Form, Function and Grammaticalization. (Typological Studies in Language 42.) Amsterdam-Philadelphia: John Benjamins Publishing.

Diessel, Holger 2012. Deixis and demonstratives. - Semantics: An International Handbook of Natural Language Meaning. Kd 3. Toim Claudia Maienborn, Klaus von Heusinger, Paul Portner. (HSK 33.) Berlin: Mouton de Gruyter, lk 2407-2431.

Diessel, Holger 2013. Distance contrasts in demonstratives. - The World Atlas of Language Structures Online. Toim Matthew Dryer, Martin Haspelmath. Leipzig: Max Planck Institute for Evolutionary Anthropology.

Dixon, R. M. W. 2003. Demonstratives: A cross-linguistic typology. - Studies in Language, kd 27, nr 1, lk 61-112.

Erelt, Mati 2017. Ellips. - Eesti keele süntaks. (Eesti keele varamu III.) Toim M. Erelt, Helle Metslang. Tartu: Tartu Ülikooli Kirjastus, lk 590-602.

Etelämäki, Marja 2009. The Finnish demonstrative pronouns in light of interaction. - Journal of Pragmatics, kd 41, nr 1, lk 25-46.

Givón, Talmy 2005. Context as Other Minds: The Pragmatics of Sociality, Cognition and Communication. Amsterdam-Philadelphia: John Benjamins Publishing Company.

Gundel, Jeanette K.; Hedberg, Nancy; Zacharski, Ron 1993. Cognitive status and the form of referring expressions in discourse. - Language, $\mathrm{kd} \mathrm{69,} \mathrm{nr}$ 2, lk 274-307.

Halliday, M. A. K.; Hasan, Ruqaiya 1976. Cohesion in English. (English Language Series.) London-New York: Routledge.

Hanks, William F. 1990. Referential Practice: Language and Lived Space among the Maya. Chicago-London: University of Chicago Press.

Hennoste, Tiit 2017. Üldlaiendid, kiilud, irdelemendid. - Eesti keele süntaks. (Eesti keele varamu III.) Toim Mati Erelt, Helle Metslang. Tartu: Tartu Ülikooli Kirjastus, 1k 481-502.

Hint, Helen 2015. Third person pronoun forms in Estonian in the light of centering theory. ESUKA-JEFUL, kd 6, nr 2, lk 105-135.

Hint, Helen; Nahkola, Tiina; Pajusalu, Renate 2017. With or without articles? A comparison of article-like determiners in Estonian and Finnish. - Lähivõrdlusi. Lähivertailuja, nr 27, lk 65-106.

Hint, Helen; Nahkola, Tiina; Pajusalu, Renate 2020. Pronouns as referential devices in Estonian, Finnish, and Russian. - Journal of Pragmatics, nr 155, lk 43-63.

Kaiser, Elsi 2010. Effects of contrast on referential form: Investigating the distinction between strong and weak pronouns. - Discourse Processes, kd 47, nr 6, lk 480-509. 
Kaiser, Elsi; Trueswell, John C. 2008. Interpreting pronouns and demonstratives in Finnish: Evidence for a form-specific approach to reference resolution. - Language and Cognitive Processes, kd 23, nr 5, lk 709-748.

Keevallik, Leelo 2011. Pro-forms as projective devices in interaction. - Discourse Processes, kd 48, nr 6, lk 404-431.

Kibrik, Andrej A. 2011. Reference in Discourse. (Oxford Studies in Typology and Linguistic Theory.) Oxford-New York: Oxford University Press.

Kibrik, Andrej A.; Khudyakova, Mariya V.; Dobrov, Grigory B.; Linnik, Anastasia; Zalmanov, Dmitrij A. 2016. Referential choice: Predictability and its limits. - Frontiers in Psychology, nr 7:1429.

Kirsipuu, Helen; Soodla, Piret; Pajusalu, Renate 2012. Referentsiaalsed noomenifraasid laste narratiivides. - Eesti Rakenduslingvistika Ühingu aastaraamat, nr 8, lk 91-107.

Labov, William 1972. Language in the Inner City: Studies in the Black English Vernacular. Philadelphia: University of Pennsylvania Press.

Labov, William; Waletzky, Joshua 1967. Narrative analysis: Oral versions of personal experience. - Essays on the Verbal and Visual Arts. Toim June Helm. Seattle-London: University of Washington Press, lk 12-44.

Larjavaara, Matti 1990. Suomen deiksis. (Suomi 156.) Helsinki: Suomalaisen Kirjallisuuden Seura.

Laury, Ritva 2005. Introduction. - Minimal Reference. (Studia Fennica. Linguistica 12.) Toim R. Laury. Helsinki: Suomalaisen Kirjallisuuden Seura, lk 7-10.

Levinson, Stephen C. 2004. Deixis. - The Handbook of Pragmatics. Toim Laurence R. Horn, Gregory Ward. Malden, MA: Blackwell Publishing, lk 97-121.

Levinson, Stephen C. 2018. Introduction. Demonstratives: patterns in diversity. - Demonstratives in Cross-Linguistic Perspective. (Language Culture and Cognition 14.) Toim S. C. Levinson, Sarah Cutfield, Michael Dunn, Nick Enfield, Sérgio Meira. Cambridge: Cambridge University Press, lk 1-42.

Lindström, Liina 2005. Finiitverbi asend lauses. Sõnajärg ja seda mõjutavad tegurid suulises eesti keeles. (Dissertationes philologiae Estonicae Universitatis Tartuensis 12.) Tartu: Tartu Ülikooli Kirjastus.

Lyons, Christopher 1999. Definiteness. Cambridge: Cambridge University Press.

Meira, Sérgio; Terrill, Angela 2005. Contrasting contrastive demonstratives in Tiriyó and Lavukaleve. - Linguistics, kd 43, nr 6, lk 1131-1152.

Pajusalu, Renate 2000. Indefinite determiners mingi and üks in Estonian. - Estonian: Typological Studies. Kd IV. (Tartu Ülikooli eesti keele õppetooli toimetised 14.) Toim Mati Erelt. Tartu: Tartu Ülikooli Kirjastus, lk 87-117.

Pajusalu, Renate 2005. Anaphoric pronouns in Spoken Estonian: Crossing the paradigms. Minimal Reference. (Studia Fennica. Linguistica 12.) Toim Ritva Laury. Helsinki: Suomalaisen Kirjallisuuden Seura, lk 107-134.

Pajusalu, Renate 2006. Death of a demonstrative: person and time. The case of Estonian too. - Linguistica Uralica, kd 42, nr 4, lk 241-253.

Pajusalu, Renate 2017a. Nimisõnafraas. - Eesti keele süntaks. (Eesti keele varamu III.) Toim Mati Erelt, Helle Metslang. Tartu: Tartu Ülikooli Kirjastus, lk 379-404.

Pajusalu, Renate 2017b. Viiteseosed. - Eesti keele süntaks. (Eesti keele varamu III.) Toim Mati Erelt, Helle Metslang. Tartu: Tartu Ülikooli Kirjastus, lk 566-589. 
Pajusalu, Renate; Kaska, Maret; Klaas-Lang, Birute; Pajusalu, Karl; Treikelder, Anu; Vihman, Virve-Anneli 2017. Characteristics of request formulation in Estonian, Finnish, French, Lithuanian and Russian. - STUF-Language Typology and Universals, kd 70, nr 3, lk 455-488.

Pajusalu, Renate; Reile, Maria; Hint, Helen; Nahkola, Tiina; Taremaa, Piia 2018. Relative clauses in spatial and narrative contexts in Estonian, Finnish, and Russian. - SKY Journal of Linguistics, kd 31, lk 107-142.

Reile, Maria 2015. Space and demonstratives: An experiment with Estonian exophoric demonstratives. - ESUKA-JEFUL, kd 6, nr 2, lk 137-165.

Reile, Maria 2016. Distance, visual salience, and contrast expressed through different demonstrative systems: An experimental study in Estonian. - SKY Journal of Linguistics, kd 29, lk 63-94.

Reile, Maria 2019. Estonian demonstratives in exophoric use: An experimental approach. (Dissertationes linguisticae Universitatis Tartuensis 34.) Tartu: Tartu Ülikooli Kirjastus.

Reile, Maria; Taremaa, Piia; Nahkola, Tiina; Pajusalu, Renate 2019. Reference in the borderline of space and discourse: A free production experiment in Estonian, Russian, and Finnish. - Linguistica Uralica, nr 3, lk 185-208.

Reile, Maria; Plado, Helen; Gudde, Harmen B.; Coventry, Kenny R. (ilmumas 2020). Demonstratives as spatial deictics or something more? Evidence from Common Estonian and Võro. - Folia Linguistica.

Sahkai, Heete 2003. Demonstrative doubling in Spoken Estonian. - Trames, kd 7, nr 2, lk 120-144.

Schegloff, Emmanuel 2007. Sequence Organization in Interaction: A Primer in Conversation Analysis. Cambridge: Cambridge University Press.

Stein, Nancy L.; Glenn, Christine G. 1979. An analysis of story comprehension in elementary-school children. - New Directions in Discourse Processing. (Advances in discourse processes 2.) Toim Roy O. Freedle. Norwood, N.J.: Ablex, lk 53-120.

Talmy, Leonard 2017. The Targeting System of Language. Cambridge, MA: The MIT Press.

Taremaa, Piia 2017. Lokatiivsete demonstratiivadverbide asetusest ja funktsioonidest liikumist väljendavate klauside näitel. - Keel ja Kirjandus, nr 6, lk 453-468.

Renate Pajusalu (snd 1963), PhD, Tartu Ülikooli üldkeeleteaduse professor (Jakobi 2, 51014 Tartu), renate.pajusalu@ut.ee

Helen Hint (snd 1987), MA, Tallinna Ülikooli humanitaarteaduste instituudi lingvistika lektor; Tartu Ülikooli eesti ja üldkeeleteaduse instituudi doktorant, akadeemilise väljendusoskuse nooremteadur (Jakobi 2, 51014 Tartu), helen.hint@ut.ee

Maria Reile (snd 1986), PhD, Tartu Ülikooli eesti ja üldkeeleteaduse instituudi eksperimentaalse pragmaatika nooremteadur (Jakobi 2, 51014 Tartu), maria.reile@ut.ee

Piia Taremaa (snd 1982), PhD, Tartu Ülikooli eesti ja üldkeeleteaduse instituudi üldkeeleteaduse teadur (Jakobi 2, 51014 Tartu), piia.taremaa@ut.ee 


\section{Reference in Estonian descriptions and narratives}

Keywords: reference, anaphora, demonstratives, personal pronouns, Estonian

This study focuses on reference in the Estonian language by taking an experimental approach to spatial and discourse reference. The aim is to reveal what is the inventory of referential devices in Estonian, and whether there are context-related factors that influence the choices made when referring. In particular, the data from two tasks are analysed. In the spatial setting, participants were asked to describe the surroundings by referring to large visible referents, i.e. houses. In the discourse setting, participants had to narrate a story based on a picture book by referring to animate and inanimate objects. Importantly, in both tasks, the speakers had to differentiate between competing referents (houses in the spatial task, and boys (as well as other objects) in the narration task). In the data, five types of referential devices occur: bare NPs (e.g. maja 'a/the house', noorem poiss 'the younger boy'), NPs with determiners (e.g. see maja 'this house', üks poiss 'a boy'), bare demonstratives (e.g. see 'this', seal 'there'), personal pronouns (i.e. tema/ta '(s)he'), and verb forms without overt subjects (e.g. seisab 'stands', jookseb 'is running'). In the spatial context, NPs both with and without determiners are used most frequently, followed by bare demonstratives. In the narrative context, bare NPs are used the most, followed by significantly less frequent personal pronouns. In both contexts, the main determiner used is see 'this'. However, in the spatial context, demonstrative adverbs are also typical determiners (e.g. siin majas 'here in the house'), whereas in the narrative context, pronouns üks 'one' and oma 'one's' are typical determiners (e.g., üks poiss 'a boy'). As such, the results show that the choice of referential devices is highly dependent on the referential context. Describing the surroundings requires the speaker to use other strategies as compared to narrating a story. Furthermore, the analysis indicates that contrast also contributes to the use of different referential units, as does the location of the competing entities (i.e. distance).

Renate Pajusalu (b. 1963), PhD, University of Tartu, Professor of General Linguistics (Jakobi 2, 51014 Tartu), renate.pajusalu@ut.ee

Helen Hint (b. 1987), MA, Tallinn University, School of Humanities, Lecturer of Linguis-
tics; University of Tartu, Institute of Estonian and General Linguistics, Doctoral Stu-
dent, Junior Research Fellow in Academic Writing and Rhetoric (Jakobi 2, 51014 Tartu),
helen.hint@ut.ee

Maria Reile (b. 1986), PhD, University of Tartu, Institute of Estonian and General Linguistics, Research Fellow in Experimental Pragmatics (Jakobi 2, 51014 Tartu), maria.reile@ut.ee

Piia Taremaa (b. 1982), PhD, University of Tartu, Institute of Estonian and General Linguistics, Research Fellow in General Linguistics (Jakobi 2, 51014 Tartu), piia.taremaa@ut.ee 